\title{
Seasonal variation in the secondary chemistry of foliar and reproductive tissue of
}

Delphinium nuttallianum

3

4

5

29 * To whom correspondence should be addressed: Tel.:(435) 752-2941 Fax: (435) 753-5681.

$30 \quad$ E-mail: daniel.cook@ars.usda.gov, reirwin@ncsu.edu

31
Daniel Cook ${ }^{1 *}$, Anthony Slominski ${ }^{2,3}$, Dale R. Gardner ${ }^{1}$, James A. Pfister $^{1}$, Rebecca E. Irwin ${ }^{2,4, *}$

${ }^{1}$ USDA ARS Poisonous Plant Research Laboratory, 1150 East 1400 North, Logan, Utah 84341

${ }^{2}$ Rocky Mountain Biological Laboratory, PO Box 519, Crested Butte, CO 81224

${ }^{3}$ Current address: Montana State University, Department of Ecology, Bozeman, MT 59715

${ }^{4}$ North Carolina State University, Department of Applied Ecology, Raleigh, NC 27695

* Corresponding authors 1)

1

2

3

(1)

5

(1)

7

28 


\section{Abstract}

32 Plant secondary compounds are critical in affecting interactions between plants and their

33 herbivores. The norditerpene alkaloids are secondary compounds in Delphinium (larkspur)

34 species which are divided into two classes: the $N$-(methylsuccinimido) anthranoyllycoctonine

35 (MSAL-type) and non MSAL-type, and are known to be toxic to herbivorous insects and

36 livestock. Alkaloid concentrations were measured in a whole plant context in vegetative and

37 reproductive tissues in D. nuttallianum at different stages of plant maturity at two locations to

38 explore how plant maturity affected alkaloid concentrations within a growing season. Alkaloid

39 concentrations differed between vegetative and reproductive tissues, with vegetative tissues

40 having significantly lower alkaloid concentrations than reproductive tissues. However, no

41 systematic differences in alkaloid concentrations were observed at different plant maturity stages

42 across the growing season. Based on the data we suggest that alkaloid allocation in different

43 plant parts of $D$. nuttallianum is influenced by life history of the plant, consistent with plant

44 defense theory. At one location, as pods mature the qualitative alkaloid composition changed

45 through structural diversification of the alkaloids present. The ecological significance of this

46 structural diversification awaits further exploration.

47

48

49

50 Keywords-Larkspur; Delphinium; norditerpene alkaloids; plant parts; life history. 


\section{1. Introduction}

52 Plant secondary compounds play an important role in affecting interactions between

53 plants and a diverse group of insects and other animals (McIntyre et al. 1981; Rosenthal and

54 Berenbaum, 1991; Adler and Kittelson 2004). Despite the overwhelming importance of

55 secondary compounds in mediating species interactions, plant species can be highly variable in

56 their secondary chemistry. A variety of factors can contribute to this variation in secondary

57 chemistry, including genetics (Orians and Fritz, 1995; Orians, 2000), resource availability

58 (Bryant et al. 1987; Orians et al. 2003), and previous patterns of damage (Hartley and Lawton,

59 1987; Baldwin, 1988). There is also recognition that plant maturity or ontogeny can contribute to

60 intraspecific variation in plant secondary chemistry (Barton and Koricheva, 2010). Optimal

61 defense theory predicts that plant tissues more closely tied to fitness should be most heavily

62 defended against herbivores or other antagonists (McKey 1974; 1979). In a whole-plant context,

63 this prediction could be extended such that as plants mature within a growing and flowering

64 season, their defense investment should be tied to the life-history stages most closely tied to

65 fitness and as a function of damage (Barton and Koricheva, 2010). However, optimal levels of

66 defense may be constrained by plant growth and the availability of carbon and other nutrients

67 used for secondary compound production (Bryant et al. 1987; Dudt and Shure, 1994; Orians et

68 al. 2003). A number of studies have reported that secondary compound concentrations in fruits

69 are equal to or greater than in leaves, consistent with optimal defense theory predictions (e.g.,

70 Zangerl and Rutledge 1996; Gardner and Pfister, 2000). However, the degree to which plant

71 ontogeny or maturity affects the expression of secondary compounds has yielded mixed results

72 (Barton and Koricheva, 2010). The goal of this study was to explore how plant maturity affected 
73 the expression of plant secondary chemistry in vegetative and reproductive tissues of the toxic

74 rangeland plant Delphinium nuttallianum (Ranunculaceae).

75 The norditerpene alkaloids are the dominant secondary compounds in Delphinium

76 (larkspur) species which are divided into two classes: the $N$-(methylsuccinimido)

77 anthranoyllycoctonine (MSAL-type) and the non-MSAL-type (Pfister et al. 1999) (Figure 1).

78 The MSAL-type alkaloids are significantly more toxic based upon assays with the generalist

79 herbivores, Spodoptera eridania and Musca domestica, as well as in a mouse model and

80 experimentation with cattle (Jennings et al. 1986; Manners et al. 1995; Cook et al. 2011).

81 Alkaloid profiles in Delphinium spp. have been shown to differ among species, populations, and

82 plant parts (Gardner et al. 2002; Cook et al. 2009; 2015). These differences can influence the

83 toxicity to grazing livestock and may influence plant interactions with insects and other animals

84 (Pfister et al. 2002; Welch et al. 2012; 2015).

85 Several studies have investigated norditerpene alkaloid concentrations in tall larkspurs

86 such as D. barbeyi, D. glaucum, and D. occidentale as a function of plant maturity and in

87 response to different environmental perturbations (Ralphs et al. 1998; Gardner and Pfister, 2000;

88 Ralphs and Gardner 2003). In tall larkspur species, the norditerpene alkaloid concentrations are

89 at their highest concentration early in the growing season and those concentrations decrease as

90 the plant grows and matures (Ralphs et al. 1997; Gardner and Pfister, 2000; Ralphs and Gardner,

91 2003). Similarly, in individual plant parts in tall larkspur, alkaloid concentrations are at their

92 highest in young immature tissues and decrease as the tissues mature and grow (Gardner and

93 Pfister, 2000; Ralphs et al. 2000). Additionally, norditerpene alkaloid concentrations vary little

94 among vegetative and floral parts at any given phenological stage, with norditerpene alkaloid 
95 concentrations generally only 1-2.5 times greater in fruits compared to leaves (Gardner and

96 Pfister, 2000; Ralphs and Gardner, 2003; Cook et al. 2013).

97 In comparison, recent research in the low larkspur D. nuttallianum demonstrated that

98 alkaloid concentrations differed dramatically among plant parts. For example, concentrations

99 were approximately 6 times greater in fruits than leaves, compared to only approximately 2 times

100 different in $D$. barbeyi. However, these data reflected plant tissues collected at a single time-

101 point when plants were fully mature, had open flowers, and maturing fruits (Cook et al. 2013).

102 On the one hand, these differences between the two species could be due to insufficient sampling

103 of D. nuttallianum and sampling at a time of year when differences are maximized. Moreover,

104 these differences in chemistry between the two species may be due to different life histories of

105 D. nuttallianum compared to tall larkspur species, such as D. barbeyi. Both D. nuttallianum and

106 tall larkspur species emerge as the snow melts; however, D. nuttallianum completes its life cycle

107 by setting seed typically early to mid-summer while $D$. barbeyi and other tall larkspur species

108 persist throughout the summer and do not flower until mid summer, generally setting seed in late

109 summer. Due to the relatively short life cycle of D. nuttallinaum, plant defense theory predicts a

110 low concentration of alkaloids in its leaves relative to other parts and relative to the leaves of

111 longer-lived species such as D. barbeyi (reviewed in Endara and Coley 2011). However, to more

112 fully test this hypothesis, measurements of secondary chemistry are needed throughout the

113 growing and flowering season of D. nuttallianum.

114 To better understand how alkaloid concentrations change as a function of plant maturity

115 for plants with different life histories, the objective of this study was to measure the qualitative

116 profiles and concentrations of the norditerpene alkaloids across vegetative and reproductive

117 tissues in D. nuttallianum over a growing season. Delphinium nuttallianum was investigated 
118 because the alkaloids in this species are well characterized in their vegetative tissue and fruits

119 (Gardner and Pfister, 2009) and has a different life history (Ewan, 1945; Williams et al. 2001)

120 than tall larkspur species such as D. barbeyi, D. glaucum, and D. occidentale. Specifically, the

121 following questions were addressed: (1) what are the qualitative profiles and concentrations of

122 the norditerpene alkaloids in vegetative and reproductive tissues and how do they vary

123 seasonally between two populations of $D$. nuttallianum, and (2) is there any evidence that the

124 qualitative norditerpene alkaloid composition changes as a function of plant part or maturity?

125

\section{2. Material and methods}

127 2.1. Plant Materials

128 Analytical samples were prepared from D. nuttallianum Pritz plant material collected 129 near Gothic, $\mathrm{CO}\left(\mathrm{N} 38^{\circ} 58.264^{\prime} \mathrm{W} 106^{\circ} 59.791^{\prime}\right)$ and Logan, UT (N 41 $55.697^{\prime} \mathrm{W} 111^{\circ}$

$13027.028^{\prime}$ ). Ten plants of $D$. nuttallianum were collected at regular intervals (approximately

131 weekly) from early flower to late pod over a 5-week period in 2011. At each collection interval,

132 plants were separated into the following parts: stems, leaves, flowers, and fruits. Plant parts

133 were air dried at room temperature and then ground using a Wiley mill or a Retsch mixer mill

134 MM301 (Haan, Germany).

135 2.2. Sample Extraction and Alkaloid Analysis

136 Plant parts (stems, leaves, flowers, fruits) were extracted and analyzed by electrospray

137 mass spectrometry using procedures previously described (Gardner et al. 1999). A measured

138 quantity of plant material $(50 \mathrm{mg})$ was extracted in $1.5 \mathrm{ml}$ of methanol for $16 \mathrm{~h}$. Reserpine (150

$139 \mu \mathrm{g})$ was added as an internal reference after extraction. The sample was mixed and then

140 centrifuged. An aliquot of the extracted sample was diluted into 1:1 methanol/1\% acetic acid for 
141 a total volume of $1 \mathrm{ml}$ for analysis. For samples with less than $50 \mathrm{mg}$ of material, the volume of

142 methanol and amount of reserpine were adjusted accordingly.

143 Mass spectra were recorded for each sample over a range of $150-800 \mathrm{~m} / \mathrm{z}$ and averaged

144 across all scans taken at $40 \%$ of peak height (total ion current). Data were calculated by

145 recording the abundance of all ions above a relative area of $0.1 \%$. The amount of a compound

146 (as represented by a single mass unit) detected was calculated based on the relative abundance of

147 the internal standard reserpine $\left(\mathrm{MH}^{+}=609\right)$. The resulting mass spectral data were reduced and

148 tabulated to a final set of quantitative values for 18 different protonated molecules $(\mathrm{m} / \mathrm{z} 414,428$,

$149454,466,468,482,494,496,508,536,552,564,578,667,669,683,697$, and 711) using a

150 method similar to that reported by Gardner et al. (2002) (Table 1). All alkaloid amounts were

151 expressed as $\mu \mathrm{g}$ alkaloid / $100 \mathrm{mg}$ plant material. Alkaloid concentrations reported here are

152 relative as they have been normalized to an internal reserpine standard.

153 Samples from both locations as well as the pods from early pod and full pod phenological

154 stages were analyzed by reverse-phase HPLC-esi $(+)$ MS using methods previously described

155 (Gardner et al. 2009). This enabled identification of the protonated molecules ( $\mathrm{m} / \mathrm{z} 669$ and 711)

156 in the different plants as a function of maturity.

157 2.4. Data Analysis

$158 \quad$ For all comparisons of alkaloid concentrations in different parts, concentrations were log-

159 transformed to improve normality. To assess if alkaloid concentrations varied with plant part

160 and time, we performed a two-way ANOVA in SAS 9.3 (SAS Institute, Cary, NC, USA).

161 Separate analyses were performed for each site (Logan, UT and Gothic, CO). Least square

162 means were calculated in SAS for the analysis; however, all means presented in this paper are 
163 unadjusted and non-transformed. When significant interactions $(\mathrm{P}<0.05)$ were detected, the

164 PDIFF option with a Tukey adjustment was used for mean comparisons.

\section{3. Results and Discussion}

166 The qualitative norditerpene alkaloid composition differed between the two collection

167 sites, with the rank order of the individual norditerpene alkaloids varying between sites (Table

168 1). The dominant MSAL-type alkaloids at Logan, UT were nudicauline $(\mathrm{m} / \mathrm{z} 711)$,

169 methyllycaconitine $(\mathrm{m} / z$ 683), and 14-deacetylnudicauline $(\mathrm{m} / z$ 669) while the dominant MSAL-

170 type alkaloids at Gothic, CO were 14-deacetylnudicauline $(\mathrm{m} / \mathrm{z} 669)$, barbinine $(\mathrm{m} / \mathrm{z} 667)$, and

171 nudicauline $(\mathrm{m} / \mathrm{z}$ 711). The protonated molecules at $\mathrm{m} / \mathrm{z} 468,466,454$, likely non-MSAL type

172 alkaloids, represented other dominant alkaloids at both collection sites. The alkaloid profiles

173 reported here for $D$. nuttallianum are consistent with previous observations for this species at the

174 same locations (Gardner and Pfister, 2009). Differences in the qualitative MSAL-type alkaloid

175 profiles between these sites may offer additional tools to study the relative role of other MSAL-

176 type alkaloids and their relative toxicity. The population at Gothic, $\mathrm{CO}$ is of unique interest

177 because the concentration of methyllycaconitine (MLA, $m / z 683$ ) is very low. All of the studies

178 to date where tall larkspurs have been dosed to cattle, the dominant MSAL-type alkaloid is

179 methyllycaconitine (Welch et al. 2012).

180 Total alkaloid concentrations showed a part $\mathrm{x}$ time interaction at Logan, UT and Gothic,

$181 \mathrm{CO}(\mathrm{P}<0.001$ in both sites $)$. Total alkaloid concentrations differed between stems, leaves, and

182 reproductive tissues (Table 2). Fruits and/or reproductive tissues generally had the highest

183 alkaloid concentration at both locations at all time points (Table 2). Stems were intermediate in

184 their alkaloid concentrations while the leaves were the lowest at both locations at all time points

185 (Table 2). The concentrations of alkaloids in the different vegetative and reproductive tissues 
186 were consistent with optimal defense theory predictions (McKey 1974; 1979). Furthermore, the

187 concentrations reported here in leaves and reproductive tissues are biologically active against

188 herbivorous insects and mammals (Jennings et al. 1986; Pfister et al. 2002). In summary, fruits

189 and/or reproductive tissues were most heavily defended as they contained the greatest

190 concentrations of total alkaloids at both locations.

191 Alkaloid concentrations have been reported to decrease over time in tall larkspurs on a

192 whole plant basis and in individual parts (Gardner and Pfister, 2000; Ralphs and Gardner, 2003).

193 For example, the MSAL-type alkaloids in leaves of $D$. barbeyi range from $18 \mathrm{mg} / \mathrm{g}$ early in the

194 summer to $1 \mathrm{mg} / \mathrm{g}$ at the end of the summer. This is thought to be due to changes in plant size,

195 resulting in diluting of the alkaloids as the plants grow, and maturity of the tissues, with older

196 tissues containing less defensive compounds than younger tissues. Alkaloid concentrations in $D$.

197 nuttallianum showed some changes between time points within parts at both locations, although

198 there were no consistent trends that occurred across all plant parts and sites (Table 2). For

199 example, alkaloid concentrations in leaves showed significant declines across some time periods

200 in both sites, whereas stems showed increased and then decreased alkaloid concentrations across

201 the season, but only at one site (Gothic, $\mathrm{CO}$ ). In addition, flowers and fruits showed no

202 statistically significant differences in alkaloid concentrations among time periods at either site

203 (Table 2). By separating plants into their constituent parts, we gained insight into the degree to

204 which individual parts were changing over time, albeit idiosyncratically. In comparison, Gardner

205 and Pfister (2007) observed few changes in the MSAL-type alkaloid concentrations measured on

206 a whole plant basis in D. nuttallianum at different stages of maturation within a flowering

207 season. 
In D. barbeyi, alkaloid concentrations in leaves and reproductive tissues at early to late

209 maturity stages differ between 1-2.5 fold (Gardner and Pfister, 2000; Ralphs and Gardner, 2003).

210 Previously we reported that total alkaloid concentrations in leaves of $D$. barbeyi were 1.9 times

211 less than those in fruits; however, in D. nuttallianum concentrations in leaves were 6 times less

212 than those found in fruits at a single collection time. We hypothesized that D. nuttallianum may

213 have much lower alkaloid concentrations in leaves compared D. barbeyi, a tall larkspur species,

214 due to differences in life history. This hypothesis is consistent with the Resource Availability

215 Hypothesis, which predicts that the leaves of longer-lived species would be more heavily

216 defended than shorter-lived species (Coley et al. 1985). D. nuttallianum is a single stemmed

217 plant growing up to 0.7 meters with 2-6 leaves and 4-48 flowers per plant, while D. barbeyi is

218 often a multi-stemmed plant growing up to 2.5 meters with 8-24 leaves per stalk and 10-50

219 flowers per stalk, often resulting in hundreds of flowers per plant (Ewan, 1945; Warnock, 1997;

220 Williams et al. 2001). Both species emerge as the snow melts; however, D. nuttallianum

221 completes its life cycle by setting seed typically within 2 months of snow melt while D. barbeyi

222 persists throughout the summer and does not flower until early to mid summer, generally setting

223 seed in late summer. Results reported here for $D$. nuttallianum showed that alkaloid

224 concentrations were always greater in reproductive tissues. Differences range from

225 approximatley 2 fold at early phenological stages to greater than 10 fold at later phenological

226 stages (Table 2). The data reported here representing changes in D. nuttallianum maturity within

227 a flowering season support our hypothesis that the differences in life history, specifically the

228 time for the plant to emerge at snow melt and set seed, is associated with the differences in

229 allocation of alkaloids across tissues within D. nuttallianum. 
Pyrrolizidine alkaloids are thought to undergo major structural diversification in the

231 shoots after translocation of an N-oxide to the shoots from the roots (Hartmann, 1999). To date

232 there is no evidence of structural diversification of the norditepene alkaloids in different tissues

233 of Delphinium spp. as a function of plant maturity. Previously we reported that the qualitative

234 alkaloid profiles in $D$. barbeyi and D. nuttallianum were similar among the different tissues of

235 each respective species. Here, the qualitative profile of alkaloids was similar among the different

236 tissues at the different collection periods with one exception. In the pods collected at Gothic,

237 CO, 14-deacetylnudicauline $(m / z$ 669) was the dominant MSAL-type alkaloid at the initial

238 collection. Initial concentrations of 14-deacetylnudicauline were $269 \pm 120 \mu \mathrm{g} / 100 \mathrm{mg}$ at the

239 early pod stage. In each collection thereafter 14-deacetylnudicauline concentrations decreased to

240 a concentration of $11 \pm 5 \mu \mathrm{g} / 100 \mathrm{mg}$ at the full pod stage. As the concentration of 14-

241 deacetylnudicauline decreased a corresponding increase in nudicauline $(\mathrm{m} / \mathrm{z} 669)$ was observed.

242 Initial concentrations of nudicauline were $29 \pm 10 \mu \mathrm{g} / 100 \mathrm{mg}$ at the early pod stage and $164 \pm 19$

$243 \mu \mathrm{g} / 100 \mathrm{mg}$ at the full pod stage. These data suggest that as pods mature 14-deacetylnudicauline

244 is acetylated to form nudicauline. Furthermore, it provides the first example of structural

245 diversification of the norditerpene alkaloids in Delphinium spp. The ecological significance of

246 this structural diversification is unknown and warrants further investigation. Similar

247 observations were not made in D. nuttallianum collected at Logan, UT as nudicauline was the

248 dominant alkaloid at all phenological stages.

249 In conclusion, norditerpene alkaloid concentrations were measured in a whole plant

250 context including vegetative and reproductive tissues in D. nuttallianum. Alkaloid

251 concentrations were consistent with predictions made by defense theory. Furthermore, the data

252 support our hypothesis that alkaloid allocation in different tissues may be influenced by the life 
253 history strategy of the plant. Lastly, we present data suggesting that as pods mature the

254 qualitative alkaloid composition may change through structural diversification of the alkaloids 255 present at some rangeland locations.

256

257 Acknowledgements

258 We wish to thank Jessie Roper for technical assistance. Field assistance and laboratory access at 259 the Rocky Mountain Biological Laboratory were provided by a grant from the National Science 260 Foundation (DEB-0841862). 


\section{References}

262 Adler, L.S., Kittelson, P.M., 2004. Variation in Lupinus arboreus alkaloid profiles and

263 relationships with multiple herbivores. Biochem. System. Ecol. 32, 371-390.

264 Baldwin, I.T., 1988. Damage-induced alkaloids in tobacco: pot-bound plants are not inducible.

265 J. Chem. Ecol. 14, 1113-1120.

266 Barton, K.E., Koricheva, J., 2010. The ontogeny of plant defense and herbivory: Characterizing

267 general patterns using meta-analysis. Amer Nat 175, 481-493.

268 Bryant, J.P., Clausen, T.P., Reichardt, P.B., McCarthy, M.C., Werner, R.A., 1987. Effect of

269 nitrogen fertilization upon the secondary chemistry and nutritional value of quaking aspen

270 (Populus tremuloides Michx.) leaves for the large aspen tortrix (Choristoneura conflictana

271 (Walker)). Oecologia 73, 513-517.

272 Coley, P.D., Bryant, J.P., Chapin, F.S., 1985. Resourse availability and plant antiherbivore

273 defense. Science 230, 895-899.

274 Cook, D., Gardner, D.R., Pfister, J.A., Welch, K.D., Green, B.T., Lee, S.T., 2009. The

275 biogeographical distribution of duncecap larkspur (Delphinium occidentale) chemotypes and 276 their potential toxicity. J. Chem. Ecol. 35, 643-652.

277 Cook, D., Green, B.T., Welch, K.D., Gardner, D.R., Pfister, J.A., Panter, K.E., 2011.

278 Differential toxicity of Duncecap Larkspur, Delphinium occidentale, chemotypes in mice and 279 cattle. Am. J. Vet Res. 72, 706-714.

280 Cook, D., Manson, J.S., Gardner, D.R., Welch, K.D., Irwin, R.E., 2013. Norditerpene alkaloid 281 concentrations in tissues and floral rewards of larkspurs and impacts on pollinators. Biochem. 282 System. Ecol. 48, 123-131. 
283 Cook, D., Welch, K.D., Green, B.T., Gardner, D.R., Pfister, J.A., Constantino, J.R., Stonecipher,

284 C.A., 2015. The relative toxicity of Delphinium stachydeum in mice and cattle. Toxicon 99, 36-

28543.

286 Dudt, J.F., Shure, D.J., 1994. The influence of light and nutrients on foliar phenolics and insect

287 herbivory. Ecology, 86-98.

288 Endara, M.-J., Coley, P. D., 2011. The resource availability hypothesis revisited: a meta-analysis.

289 Funct. Ecol. 25, 389-398.

290 Ewan, J., 1945. A synopsis of the North American species of Delphinium. Univ. Colorado

291 Studies, Series D 2:55-244.

292 Gardner, D.R., Panter, K.E., Pfister, J.A., Knight, A.P., 1999. Analysis of toxic norditerpenoid

293 alkaloids in Delphinium species by electrospray, atmospheric pressure chemical ionization, and

294 sequential tandem mass spectrometry. J. Agric. Food. Chem. 47, 5049-5058.

295 Gardner, D.R., Pfister, J.A., 2000. Late season toxic alkaloid concentrations in tall larkspur

296 (Delphinium spp.) J. Range Mange. 53, 329-334.

297 Gardner, D.R., Pfister, J.A., 2007. Toxic alkaloid concentrations in Delphinium nuttallianum,

298 Delphinium andersonii, and Delphinium geyeri in the intermountain region. Rangeland Ecol.

299 Manag. 60, 441-446.

300 Gardner, D.R., Pfister, J.A., 2009. HPLC-MS analysis of toxic norditerpenoid alkaloids:

301 Refinement of toxicity assessment of low larkspurs (Delphinium spp.). Phytochem. Anal. 20,

302 104-113.

303 Gardner, D.R., Ralphs, M.H., Turner, D.L., Welsh, S.L., 2002. Taxonomic implications of

304 diterpene alkaloids in three toxic tall larkspur species (Delphinium spp.). Biochem. System. Ecol.

$30530,77-90$. 
306 Hartley, S.E., Lawton, J.H., 1987. Effects of different types of damage on the chemistry of birch

307 foliage, and the responses of birch feeding insects. Oecologia 74, 432-437.

308 Hartmann, T., 1999. Chemical ecology of pyrrolizidine alkaloids. Planta, 207, 483-495.

309 Jennings, K.R., Brown, D.G., Wright, D.P., 1986. Methyllycaconitine, a naturally occurring

310 insecticide with a high affinity for the insect cholinergic receptor. Experientia 42, 611-613.

311 Joshi, B.S., Desai, H.K., El-Kashoury, E.A., Pelletier, S.W., Olsen, J.D., 1989. Delbidine, an

312 alkaloid from a hybrid population of Delphinium occidentale and Delphinium barbeyi.

313 Phytochemistry 28, 1561-1563.

314 Joshi, B.S., El-Kashoury, E.A., Desai, H.K., Holt, E.M., Olsen, J.D, Pelletier, S.W., 1988. The

315 structure of barbeline, an unusual $\mathrm{C}_{19}$-diterpenoid alkaloid from Delphinium barbeyi Huth. Tet.

316 Lett. 29, 2397-2400.

317 Kulanthaivel, P., Holt, E.M., Olsen, J.D., Pelletier, S.W., 1990. Barbisine a $\mathrm{C}_{20}$-diterpendoid

318 alkaloid from Delphinium barbeyi. Phytochemistry 29, 293-295.

319 Kulanthaivel, P., Pelletier, S.W., Olsen, J.D., 1988. Three new $\mathrm{C}_{19}$-diterpendoid alkaloids from

320 Delphinium occidentale. S. Wats. Heterocycles 27, 339-342.

321 Manners, G.D., Panter, K.E., Pelletier, S.W., 1995. Structure-activity relationships of

322 norditerpenoid alkaloids occurring in toxic larkspur (Delphinium) species. J. Nat. Prod. 58, 863-

323869.

324 Manners, G.D., Panter, K.E., Pfister, J.A., Ralphs, M.H., James, L.F., 1998. The characterization

325 and structure-activity evaluation of toxic norditerpenoid alkaloids from two Delphinium species.

326 J. Nat. Prod. 61, 1086-1089. 
327 Manners, G.D., Wong, R.Y., Benson, M., Ralphs, M.H., Pfister, J.A., 1996. The characterization

328 and absolute stereochemistry of barbaline, a diterpenoid alkaloid from Delphinium barbeyi.

329 Phytochemistry 42, 875-879.

330 McIntyre, J.L., Dodds, J.A. Hare, J.D., 1981. Effects of localized infections of Nicotiana

331 tobacum by tobacco mosaic virus on systemic resistance against diverse pathogens and an insect.

332 Phytopathol. 71, 297-301.

333 McKey, D. 1974. Adaptive patterns in alkaloid physiology. Am. Nat. 108, 305-320.

334 McKey, D. 1979. The distribution of secondary metabolites within plants. In Rosenthal, G.A.,

335 Janzen, D.H. (eds) Herbivores: their interaction with secondary plant metabolites. Orlando, FL:

336 Academic Press.

337 Orians, C.M., 2000. The effects of hybridization in plants on secondary chemistry: implications

338 for the ecology and evolution of plant-herbivore interactions. Am. J. Bot. 87, 1749-1756.

339 Orians, C.M., Fritz, R.S., 1995. Secondary chemistry of hybrid and parental willows: Phenolic

340 glycosides and condensed tannins in Salix sericea, S. eriocephala, and their hybrids. J. Chem.

341 Ecol. 21, 1245-1253.

342 Orians, C.M., Lower, S., Fritz, R.S., Roche, B.M., 2003. The effects of plant genetic variation

343 and soil nutrients on secondary chemistry and growth in a shrubby willow, Salix sericea: patterns

344 and constraints on the evolution of resistance traits. Biochem. System. Ecol. 31, 233-247.

345 Pelletier, S.W., Dailey, O.D. Jr, and Mody, N.V., 1981. Isolation and structure elucidation of the

346 alkaloids of Delphinium glaucescens. J. Org. Chem. 46, 3284-3293.

347 Pelletier, S.W., Kulanthaivel, P., Olsen, J.D., 1989. Alkaloids of Delphinium barbeyi.

348 Phytochemistry 28:1521-1525. 
349 Pfister, J.A., Gardner, D.R., Panter, K.E., Manners, G.D., Ralphs, M.H., Stegelmeier, B.L.,

350 Schoch, T.K., 1999. Larkspur (Delphinium spp.) poisoning in livestock. J. Nat. Toxins 8, 81-94.

351 Pfister, J.A., Ralphs, M.H., Gardner, D.R., Stegelmeier, B.L., Manners, G.D., Panter, K.E., LEE,

352 S.T., 2002. Management of three toxic Delphinium species based on alkaloid concentrations.

353 Biochem. Syst. Ecol. 30, 129-138.

354 Ralphs, M.H., Gardner, D.R., 2003. Distribution of norditerpene alkaloids in tall larkspur plant 355 parts through the growing season. J. Chem. Ecol. 29, 2013-2021.

356 Ralphs, M. H., Gardner, D.R., Pfister, J.A., 2000. A functional explanation for patterns of

357 norditerpenoid alkaloid levels in tall larkspur (Delphinium barbeyi). J. Chem. Ecol. 26, 1595-

3581607.

359 Ralphs, M.H., Manners, G.D., Gardner, D.R., 1998. Influence of light and photosynthesis on

360 alkaloid concentration in larkspur. J. Chem. Ecol. 24, 167-182.

361 Ralphs, M.H., Manners, G.D., Pfister, J.A., Gardner, D.R., James, L.F., 1997. Toxic alkaloid

362 concentration in tall larkspur species in the western US. J. Range Mange. 50, 497-502.

363 Rosenthal, G., Berenbaum, M., (Eds.), 1991. Herbivores: Their Interactions with Secondary

364 Plant Metabolites, 2nd edn. Academic Press, San Diego, CA.

365 Warnock, M.J., 1997. Delphinium Linnaeus. Flora North America 3, 196-240.

366 Welch, K.D., Cook, D., Green, B.T., Gardner, D.R., Pfister, J.A., McDaneld, T.G., Panter, K.E.,

367 2015. Adverse effects of larkspur (Delphinium spp.) on cattle. Agriculture 5, 456-474.

368 Welch, K.D., Green, B.T., Gardner, D.R., Cook, D., Pfister, J.A., Panter, K.E., 2012. The effect 369 of 7, 8-methylenedioxylycoctonine-type diterpenoid alkaloids on the toxicity of tall larkspurs in 370 cattle. J. Anim. Sci. 90, 2394-2401. 
371 Williams, C.F., Ruvinsky, J., Scott, P.E., Hews, D.K., 2001. Pollination, breeding system, and 372 genetic structure in two sympatric Delphinium (Ranunculaceae) species. Am. J. Bot. 88, 16233731633.

374 Zangerl, A.R., Rutledge, C.E., 1996. The probability of attack and patterns of constitutive and 375 induced defense: a test of optimal defense theory. Am. Nat. 147, 599-608. 
376 Table 1. Representative alkaloid profile showing relative concentrations of individual protonated 377 ions from Delphinium nuttallianum collected at Gothic, CO and Logan, UT

\begin{tabular}{|c|c|c|c|c|}
\hline \multirow[b]{2}{*}{$\mathrm{m} / \mathrm{z}^{\mathrm{a}}$} & \multirow[b]{2}{*}{ Possible Alkaloids ${ }^{a}$} & \multirow[b]{2}{*}{ Alkaloid Type } & \multicolumn{2}{|c|}{$\mu \mathrm{g}$ alkaloid/ $100 \mathrm{mg}^{\mathrm{b}}$} \\
\hline & & & Gothic, CO & Logan, UT \\
\hline 414 & 11,13-Diacetyhetisine & non-MSAL & 1 & 7 \\
\hline 428 & Geyerine & non-MSAL & 0 & 25 \\
\hline 454 & Delcosine, Delectinine & non-MSAL & 42 & 5 \\
\hline 466 & Deltamine, 14-Dehydrobrowniine & non-MSAL & 53 & 6 \\
\hline 468 & Delsoline, Lycoctonine & non-MSAL & 135 & 11 \\
\hline 482 & Delphatine & non-MSAL & 28 & 1 \\
\hline 494 & Dictyocarpine & non-MSAL & 4 & 9 \\
\hline 496 & 14-Acetyldelectinine, 6-Epi-pubescenine & non-MSAL & 5 & 5 \\
\hline 508 & Deltaline & non-MSAL & 12 & 3 \\
\hline 536 & 14-Acetly dictyocarpine & non-MSAL & 0 & 1 \\
\hline 552 & Glaucedine & non-MSAL & 0 & 0 \\
\hline 564 & Glaucerine & non-MSAL & 3 & 0 \\
\hline 578 & Barbisine, Glaucenine & non-MSAL & 1 & 1 \\
\hline 667 & Barbinine & MSAL & 186 & 19 \\
\hline 669 & 14-Deacetylnudicauline, 16-Deacetylgeyerline & MSAL & 214 & 37 \\
\hline 683 & Methyllycaconitine & MSAL & 3 & 33 \\
\hline 697 & Bearline and isomers & MSAL & 24 & 21 \\
\hline 711 & Geyerline, Nudicauline, Acetylgrandiflourine & MSAL & 12 & 202 \\
\hline
\end{tabular}

380 a Alkaloid identification taken from Pelletier et al., 1981, 1989; Joshi et al., 1988,1989;

381 Kulanthaivel et al., 1988, 1990; Manners et al., 1996, 1998.

$383{ }^{b}$ Relative alkaloid concentrations per $100 \mathrm{mg}$ of plant material. Concentrations were normalized 384 to an internal reserpine standard. 
385 Table 2. Norditerpene alkaloid concentrations (means \pm SE) in stems, leaves, flowers, and pods 386 of Delphinium nuttallianum collected at different phenological stages and locations. (A) Gothic, 387 CO and (B) Logan, UT.

388

389 A.

\begin{tabular}{|c|c|c|c|c|c|c|}
\hline \multirow[t]{2}{*}{ Gothic, CO } & \multicolumn{6}{|c|}{$\mu g$ alkaloid/ $100 \mathrm{mg}^{\mathrm{a}, \mathrm{b}, \mathrm{c}, \mathrm{d}}$} \\
\hline & Time 1 (Bud) & Time 2 & Time 3 (Early Pod) & Time 4 & Time 5 & Time 6 (Full Pod) \\
\hline stem & $415 \pm 27^{a, 1,2}$ & $562 \pm 84^{a, 1}$ & $690 \pm 130^{a, 1}$ & $165 \pm 35^{b, c, 2}$ & $188 \pm 45^{b, c, 2}$ & $47 \pm 17^{b, 3}$ \\
\hline leaf & $229 \pm 50^{a, 1}$ & $246 \pm 68^{\mathrm{a}, 1}$ & $194 \pm 23^{b, 1}$ & $52 \pm 15^{c, 2}$ & $119 \pm 32^{c, 1,2}$ & $111+61^{\mathrm{b}, 1,2}$ \\
\hline fl ower & $341 \pm 39^{a, 1}$ & $558 \pm 109^{a, 1}$ & $726 \pm 185^{a, b, 1}$ & $380 \pm 36^{a, b, 1}$ & $474 \pm 68^{a, b, 1}$ & \\
\hline fruit & & & $2009 \pm 730^{a, 1}$ & $648 \pm 63^{a, 1}$ & $661 \pm 114^{a, 1}$ & $452 \pm 62^{a, 1}$ \\
\hline
\end{tabular}

391

392 B.

\begin{tabular}{|c|c|c|c|c|c|}
\hline \multirow[t]{2}{*}{ Logan, UT } & \multicolumn{5}{|c|}{$\mu \mathrm{g}$ alkaloid/ $100 \mathrm{mg}^{\mathrm{a}, \mathrm{b}, \mathrm{c}, \mathrm{d}}$} \\
\hline & Time 1 (Bud) & Time 2 & Time 3 (Early Pod) & Time 4 & Time 5 (Full Pod) \\
\hline stem & $142 \pm 21^{a, 1}$ & $100 \pm 16^{a, 1}$ & $104 \pm 23^{a, 1}$ & $99 \pm 21^{a, 1}$ & $64 \pm 15^{b, 1}$ \\
\hline leaf & $62 \pm 36^{b, 1}$ & $11 \pm 2^{b, 2}$ & $16 \pm 9^{b, 1,2}$ & $4 \pm 1^{b, 2}$ & $5 \pm 1^{c, 2}$ \\
\hline fl ower/fruit & $170 \pm 21^{a, 1}$ & $160 \pm 18^{a, 1}$ & $143 \pm 17^{a, 1}$ & $363 \pm 59^{a, 1}$ & $408 \pm 38^{a, 1}$ \\
\hline
\end{tabular}

${ }^{a}$ Different letters within a column represent statistical significance $(\mathrm{P}<0.05)$ between different plant parts.

${ }^{\mathrm{b}}$ Different numbers within a row represent statistical significance $(\mathrm{P}<0.05)$ between different

$403{ }^{\mathrm{c}}$ Each phenological stage represents 10 plants separated into plant parts. normalized to an internal reserpine standard. 
Figure Legends

411

412 Figure 1. Structure of select norditerpene alkaloids in Delphinium species.

413

414 Figure 2. 14-Deacetylnudicauline and nudicauline concentrations ( $\mu \mathrm{g} / 100 \mathrm{mg}$ dry plant

415 material, means \pm SE) in pods of Delphinium nuttallianum at early pod and full pod phenological

416 stages from Gothic, CO. Different letters above each bar represent statistical significance at

$417 \mathrm{P}<0.05$. 
418

419

420

421

422

423

424

425

426

427

428

429

430

431

432

433

434

435 Deltaline (MDL-type)
436

437

438

439

440

441

442

443

444

445

446

447

448

449

450

451

452

453

454

455

456

457

458

459

460

461

462

463

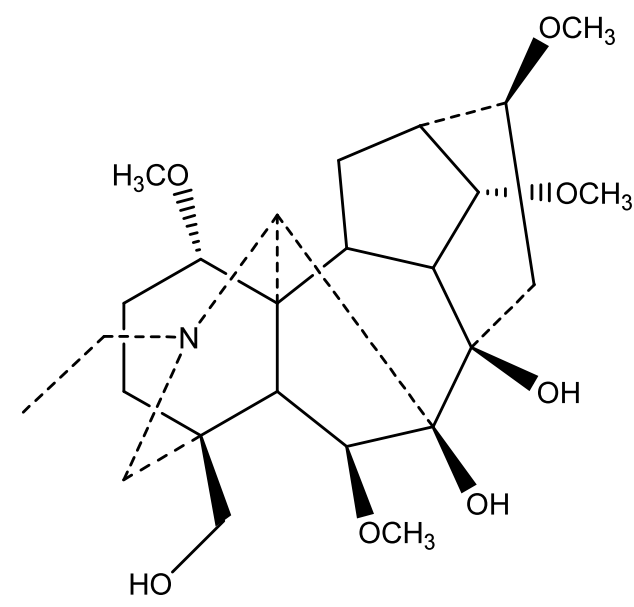

Lycoctonine (MDL-type)

$\mathrm{HO}$
Figure 1.
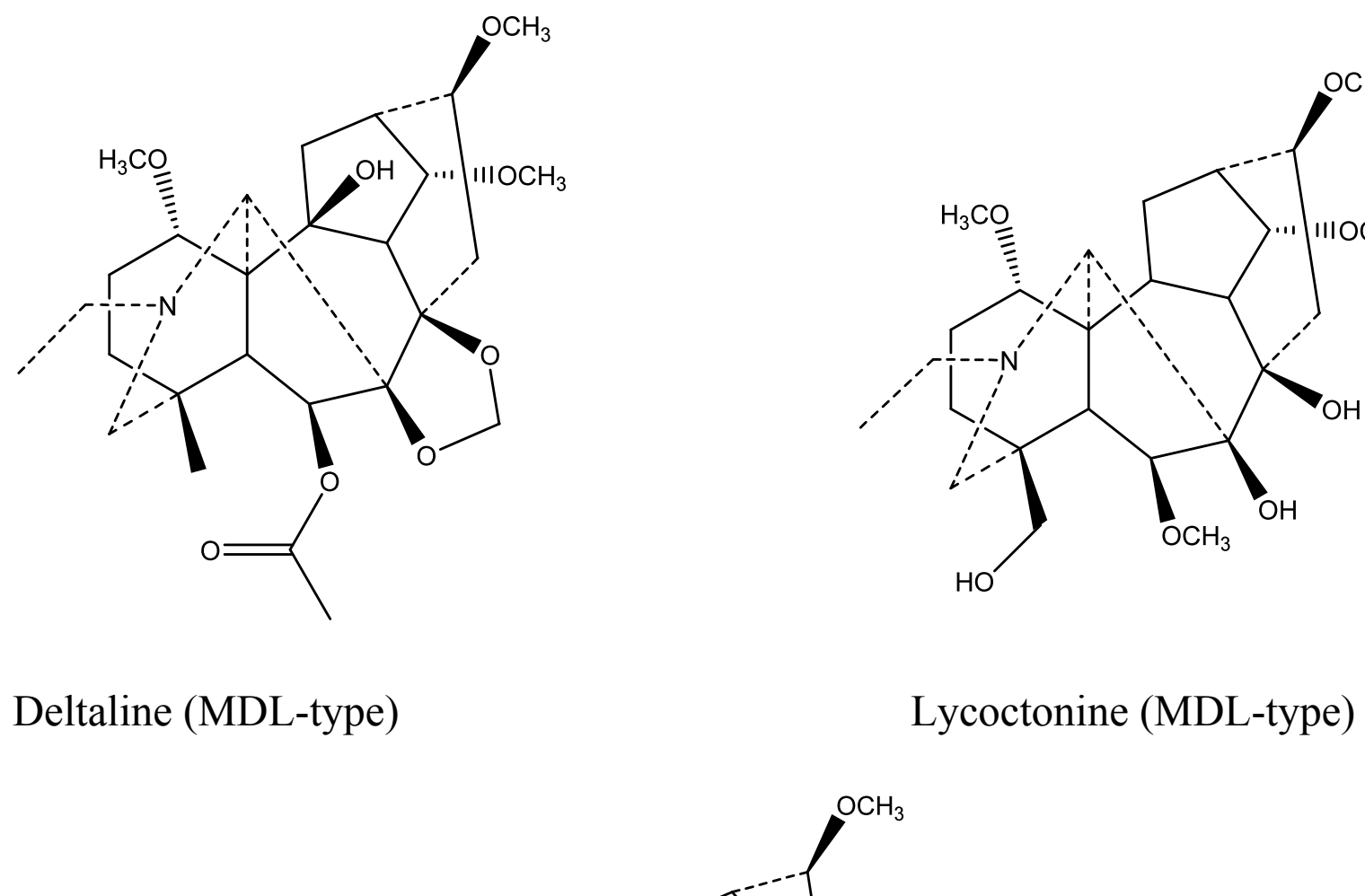
464 Figure 2.

465

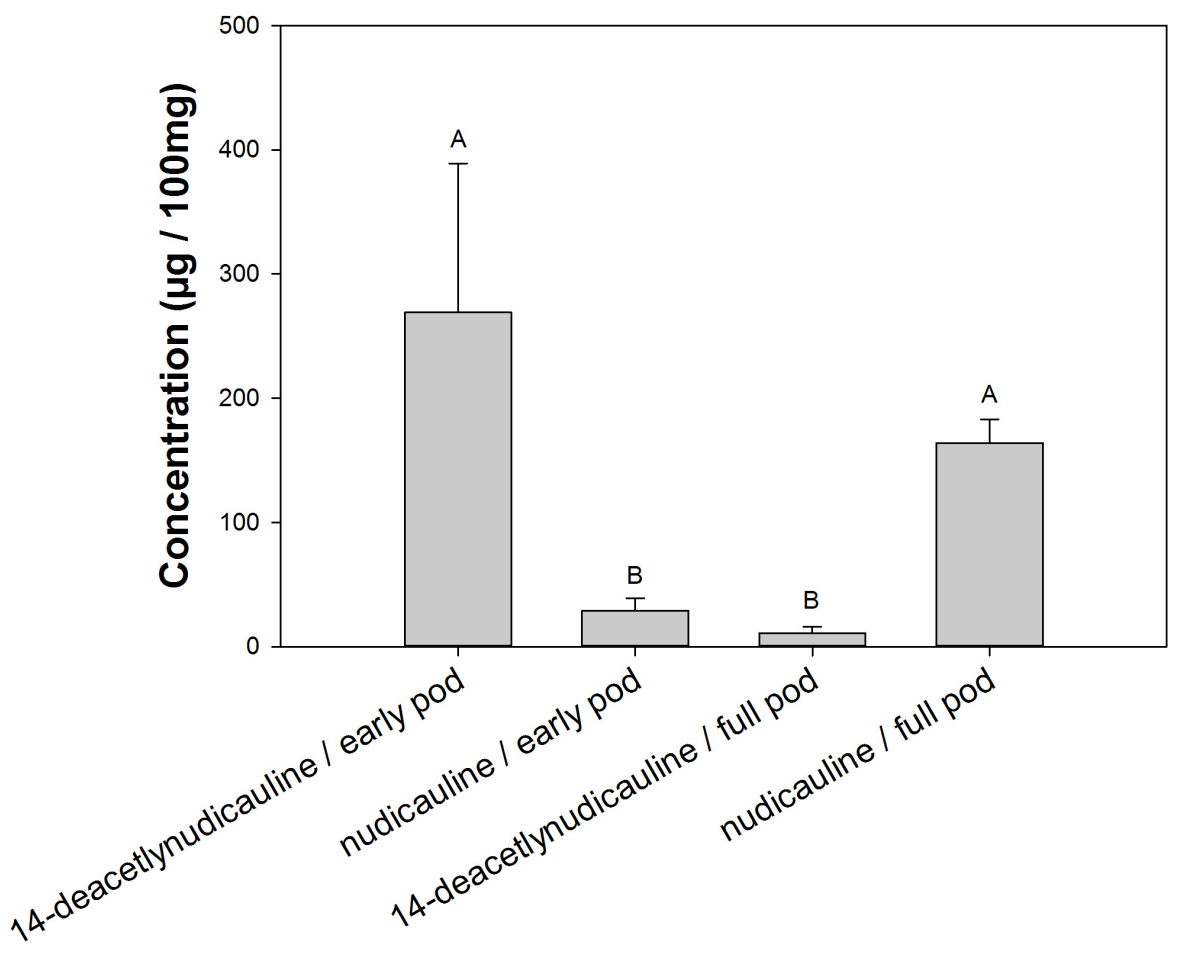

